\title{
Human Capital Development, Economic Rejuvenation and Stable Long-Term Growth: The Case of Nigeria
}

\author{
Martins lyoboyi \\ Department of Economics \& Development Studies, Federal University, Dutsin-ma, Katsina, Nigeria \\ Tel: +2348037954183 \\ E-mail address: miyoboyi@gmail.com
}

\begin{abstract}
The paper investigates the relative impact of human capital development on economic rejuvenation and growth in Nigeria form 1981 to 2010, using the bounds testing approach to cointegration. The study utilized a combined proxy of education and health to capture the influence of human capital on growing and consequently rejuvenating an economy. Fixed capital and human capital were found to be positively associated with economic growth in both the short and long run, while Granger-causing economic growth in the period of study, implying the imperatives of using them to rejuvenate an economy. The stability of the coefficients of the estimated model is confirmed by the CUSUM and CUSUMSQ tests. The paper showed that for Nigeria's economic rejuvenation and long-term stable growth, emphasis should be placed on deliberately developing the country's vast human resources.
\end{abstract}

Keywords: Cointegration; Economic rejuvenation; Growth; Human Capital

JEL classification: C01, C22, H51, I18.

\section{INTRODUCTION}

Human capital development is the conscious and deliberate building of capacity, including the harnessing of the human resources with a view to developing the full potential of a given society. It is thus imperative in the economic development process of a country. The development of a nation's human capital on a sustainable basis is a sine qua non for its economic transformation and social progress.

Education is a key driver of human capital development. The importance of education to human beings has been articulated in various documents which include the Universal Declaration of Human Rights (1948), the International Covenant on Economic, Social and Cultural Rights (1966) and the African Charter on Human and Peoples' Rights (1981). The relationship between education and development is well established, such that education is a key index of development. The literature is replete with how schooling improves productivity and engenders empowerment (UNESCO, 2002).

Nigeria has for long been lost in the development wilderness, though it has made frantic efforts at exiting the woods. In the 1960's her economy compared favourably with such 
countries as Malaysia, China, Brazil and India. With vast human and natural resources, coupled with a vast youthful population, it is a paradox of monumental proportions that she is still bedeviled by a plethora of development quagmires. Political opportunism, policy summersaults and inert leadership have had untold negative impact on the economy, with the consequence that the country has had to nosedive from a productive state in the 1960s to one of high dependence on oil revenues, which has negatively impacted her hitherto productive capacity.

The paper critically examines the place of human capital development in the rejuvenation of Nigeria's economy. Following the introduction, the rest of this paper is organised as follows. Literature and theoretical issues are covered in section 2. Section 3 presents the econometric methodology used. In section 4, the empirical results are dealt with. The study is concluded in section 5 .

\section{LITERATURE AND THEORETICAL ISSUES}

Harbison (1973) was apposite when he asserted that, what constitute the ultimate basis for the wealth of nations are human resources, as national development is carried forward, not by capital and natural resources which are passive factors of production but human beings, who being active agents in the production process, accumulate capital, exploit natural resources and consequently build social, economic and political organizations.

The terms "manpower" and "human resources" are used synonymously with human capital. Human capital is a generic term embracing the totality of energies, experience, expertise and knowledge available to a country (Diejomaoh, 1978). The spectrum of human capital extends from skills originating from the scientific, technical, and managerial to engineering horizons, embracing the most valuable resources of a nation. Economic growth and by extension economic development is positively correlated to the elasticity and quality of a country's human resources.

The development of a nation's human capital involves the systematic and sustained efforts through manpower planning, a scheme involving allocative labour inputs to training and education in tandem with a country's growth and developmental needs. This implies the projection of manpower requirements, the development and sustenance of adequate, efficient and effective training and educational programmes in a mix that efficiently allocates scarce labour resources with a view to eliminating labour shortages and surpluses (Anyanwu et al., 1997). It is no surprise therefore to find in most developing countries a direct relationship between the level of manpower (human capital) development and productive capacity. A nation is less productive not so much as by the quantum of its natural resources as by the skills and knowledge possessed by its populace. A society's capacity to produce, commercialize and utilize knowledge is fast becoming fundamental when underpinned on growth initiatives, so that countries' comparative advantage is shifting from emphasis on natural endowments to one of knowledge engineering.

Modern growth theory suggests that economic growth is reflective of human capital accumulation. Whereas controversial and inconsistent results have been produced from macro studies (Pritcell, 1996), many studies at the micro level have shown a consistently positive relationship between labour productivity and the level of education of the workforce (Trostel et al., 2002). The implication of this is that the more education and training at the disposal of an individual, the more the level of employability, productivity and earnings. Being thus a worthwhile and substantial investment, human capital development is the key to 
the reactivation of a nation's workforce productivity, since such undertaking will equip the citizenry with requisite skills and knowledge imperative for higher future earnings, savings and investment. Human capital development is linked to the educational system. Since human capital is encapsulated in the individual's ability and efficiency to engage in the transformation of raw materials into greater values, the nexus is that the educational system provides the leverage on which these skills can be transmitted. It is therefore conceivable why the analysis of human capital by experts exigently deals with such metrics as literary rates (Azariades \& Drazen, 1990), years of schooling (Cohen \& Soto, 2007), rates of school enrolment (Barro, 1991) and test scores (Hanushek \& Woessman, 2009).

Although there is a substantial amount of work which investigates the impact of gross domestic product (GDP) on health expenditures (e.g. Di Matteo \& Di Matteo, 1998; Thornton, 2002), very little has been done in terms of examining the impact of health on a country's GDP. Mushkin (1962) and Becker (1962) maintained that health is a veritable factor in human capital accumulation and consequently to productivity gains, so that it is apposite to consider health as a form of human capital.

It is generally believed that health is a stimulant of economic growth (Barro \& Lee, 1994; Sachs \& Warner, 1997). This is because the better the health of the worker, the higher their productivity. Better health in the form of adult survival rate or higher calorie intake is capable of inducing higher productivity. Consequently, it is found that workers with better health tend to earn higher wages which enable them consume and save more, both of which lead to higher economic growth (Leibenstein, 1957; Strauss \& Thomas, 1998; Chakraborty \& Das, 2005).

The nexus between improved health and schooling is profusely discussed in the literature. According to Kalemli-Ozcan et al. (2000), the incentive to acquire education is higher given that students with better health have, on the average, lower rate of absenteeism and higher cognitive functioning. In essence, the tendency for increased education and the acquisition of knowledge is improved, the better the health of the citizens, and this accounts for improved productivity.

\section{1. Human Capital and Economic Rejuvenation}

Economic rejuvenation is used here to refer to a sustained increase in a country's productive capacity from a previous period of stagnancy or depression. Human capital is a major impetus to the realization of an exit from economic retrogression to an upward trend in productivity. The imperative of education and investment in human capital in this regard is unassailable. This is principally borne out of the role of technological innovation which investment in human capital necessitates. Barro and Sala-i-Martin (1997) asserted that human capital accumulation via education and on-the-job training promotes technological adaptation as well as fosters improved productivity. By improving literacy rate, for instance, a country can rejuvenate its economy. According to Azariadis and Drazen (1990), a country's GDP growth for the 20-year period 1960-1980 was significantly determined by the literacy rate of 1960. This is amply corroborated by the studies undertaken by Mankiw et al. (1992) which showed that for non-oil exporting countries, there was an elasticity of per capita GDP to enrolment rate of 0.66 , with the conclusion that for the period 1960 to 1985 , non-convergence in income levels can be explained by differences in rates of school enrolment.

It need be said that although human capital contributes significantly to growth in output per worker, studies have shown that the contribution of physical capital has been crucial, suggestive of the fact that an economy's efficiency and investment levels are also pertinent to the transformative process (Collins, 2007). The empirical study suggests an important factor, 
that of the importance of human capital to economic growth to explore by way of research the nexus between the education of individuals vis-à-vis their labour productivity. Thus, a study of micro linkages is fundamental to the true appreciation of how the skills garnered through education and training are translated into output at the aggregate level.

For human capital to generate output for an economy's rejuvenation, the skills acquired by the individual must be utilized in the labour market. Knowledge must be transformed to goods and services for it to have bearing on total productivity and for a depressed and low low-capacity utilization economy to be on the upward growth trajectory. Son (2008) observed that in the Philippines, in the period 1997-2003, there was an increased employability of working age population of household with secondary and tertiary education while there was a decrease in employment of those with primary education. That the economy did not generate the increased productivity via higher education of people with secondary and tertiary education can be explained as a case of crowding-out of less educated people by those more educated accepting jobs where their productivity was lower. The implication of this is that despite higher education, economic growth may not be generated in a country where the labour market is either not generating the requisite jobs for the available skills or where the educational system is itself defective and not generating the skills required by industry.

The transmission of acquired skill and training into goods and services is particularly disturbing in Nigeria. An economy geared towards productivity needs to have skills and training reflective of industrial needs. Economic rejuvenation requires going beyond the rhetoric of universal basic education or the increase in the establishment of educational institutions, funding and the like, to one in which there is congruence between the demands of industry and the supply of skills by educational and training institutions.

Having the right type of education for development is imperative if human capital development must lead an economy away from downward production trajectory. According to Pritchett (1996), despite all the expansion in education since the 1960s, it has not led to the expected expansion in economic growth, when information especially for developing countries is considered. The implication of this is that human capital development should put into consideration the quality of education and the institutions themselves. Consequently, it is argued that very low quality education is incapable of producing human capital while rentseeking may well be the result of using bad institutions to build human capital. It is therefore germane that in considering human capital in its entirety, emphasis must be given to both micro as well as macro studies. This is underpinned on the fact that while at the macro level, average correlations between education and economic growth are considered, at the micro level, the use of human capital, the educational system and the conditions prevailing in the labour market are the focus.

\section{MATERIALS AND METHODS}

\section{1. Sources of Data}

For the study, annual data covering the period from 1981-2010 was used. The data was gathered from various issues of the Central bank of Nigeria and the International Monetary Fund. Data on gross domestic product, education and health expenditures, and gross fixed capital formation were obtained from various issues of Statistical Bulletin of the Central Bank of Nigeria. All the variables employed in the study were converted from nominal to real terms, using the consumer price index, and consequently divided by the figure of population to obtain per capita values respectively. Data on Nigeria's population was obtained from the 
International Monetary Fund. All the variables were initially transformed into natural logarithms before computations.

\section{2. Model Specification and Estimation Procedure}

The literature is extant on the determinants of economic growth. Consequently, the functional form adopted in the present study is presented by first specifying an aggregate production function:

$$
Y=A K^{\beta_{1}} W^{\beta_{2}}
$$

where $\mathrm{Y}$ is real gross domestic product (aggregate production), A is total factor productivity, $\mathrm{K}$ is fixed (physical) capital stock, and $\mathrm{W}$ is the human capital stock (comprising education and health). On the basis of the theoretical framework, the above specification of the aggregate production function may be written in log form as follows:

$$
\log \mathrm{RGDP}=\beta_{0}+\beta_{1} \log R G D P_{t-1}+\beta_{2} \log F K+\beta_{3} \log H K+\varepsilon_{t}
$$

where:

RGDP $=$ Real gross domestic product;

FK $=$ Fixed capital;

$\mathrm{HK}=$ Human capital;

$\beta_{0}$ is the intercept term and $\varepsilon_{t}$ the white noise error term.

Economic growth was proxied using real GDP per capita, physical capital by gross fixed capital formation per capita, and human capital by expenditures on education, health and other social and community services per capita. The intuition from equation 2 is that economic growth is a function of its past values, the stocks of fixed and human capital respectively. The study employed the bounds testing (Autoregressive Distributed Lag) approach to cointegration, in order to examine the long run and short run relationships between economic growth and human capital development. The following procedure was adopted. First, the properties of the times series used in the study are investigated to determine their order of integration. The Augmented Dickey Fuller (ADF) and the PhilipsPerron (PP) unit root tests were employed. Second, the existence of a cointegraton relationship among the variables was investigated following the Autoregressive Distributed Lag approach developed by Perasan et al. (2001). The choice of this framework is due to its advantages in small samples over traditional approaches such as those of Engle and Granger (1987) and Johansen and Juselius (1990). The procedure is applicable irrespective of whether the underlying regressors are purely $\mathrm{I}(0)$, purely $\mathrm{I}(1)$ or fractionally cointegrated. Moreover, the ARDL procedures ensure that the long and short run parameters of a model can be estimated simultaneously. In addition, its statistical properties in small samples are robust and superior to other tests of cointegration. To test for cointegration, two steps were followed. In the first place, the F-test was conducted by imposing restrictions on the estimated long run coefficients. The null and alternative hypotheses are stated as follows:

$$
\mathrm{H}_{\mathrm{o}}=\beta_{1}=\beta_{2}=\beta_{3}=0 \text { against the alternative hypothesis } \mathrm{H}_{1}=\beta_{1} \neq \beta_{2} \neq \beta_{3} \neq 0
$$

Third, the long run relationship between growth and human capital development was estimated, closely followed by the short run coefficients, this achieved using the error 
correction representation of the ARDL specification, in order to establish the speed of adjustment to equilibrium. The Autoregressive Distributed Lag (ARDL) model of the specification in equation 2 is presented as follows:

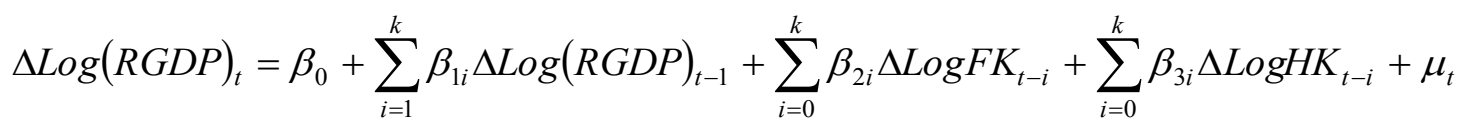

The unrestricted error correction model which follows the order of ARDL specification in equation 3 is presented in equation 4 :

$$
\begin{aligned}
& \Delta \log (R G D P)_{t}=\beta_{0}+\sum_{i=1}^{k} \beta_{1 i} \Delta \log (R G D P)_{t-1}+\sum_{i=0}^{k} \beta_{2 i} \Delta \log F K_{t-i}+\sum_{i=0}^{k} \beta_{3 i} \Delta \log H K_{t-i}+ \\
& \sum_{i=0}^{k} \Phi_{1} \log R G D P_{t-1}+\Phi_{2}{\log F K_{t-1}}+\Phi_{3} H K_{t-1}+E C M_{t-1}+\varepsilon_{t}
\end{aligned}
$$

where, the parameters $\alpha_{i}: \mathrm{i}=1,2,3$ are the short-run dynamic coefficients, while the parameters $\Phi_{i}: \mathrm{i}=1,2,3$ are the long-run multipliers.

A priori, both physical capital and human capital are expected to be positively correlated with growth. The presumptive signs of the variables are $\beta_{1}>0, \beta_{2}>0, \beta_{3}>0$.

\section{RESULTS AND DISCUSSION}

Granger causality test results are presented in Table 1.

Table 1. Granger Causality Tests.

\begin{tabular}{|c|c|c|c|}
\hline Null Hypothesis & F-statistics (P-value) & Decision & Conclusion \\
\hline $\begin{array}{c}\text { 1) FK and HK } \\
\text { FK does not Granger Cause HK }\end{array}$ & $\begin{array}{l}1.69039(0.2016) \\
1.74646(0.1888)\end{array}$ & $\begin{array}{c}\text { Accept } \\
\text { Accept }\end{array}$ & Independent \\
HK does not Granger Cause FK & $1.31416(0.3136)$ & Accept & Unidirectional \\
\hline 2) RGDP and HK & $5.52074(0.0052)$ & Reject & Unidirectional \\
RGDP does not Granger Cause HK & $0.83039(0.5491)$ & Accept \\
HK does not Granger Cause RGDP & $9.01108(0.0005)$ & Reject & \\
\hline 3) RGDP and FK & Source: Author's computations. & \\
FK does not Granger Cause RGDP & & \\
\hline
\end{tabular}

The results of Granger Causality test in Table 1 suggest that unidirectional causality runs from HK to RGDP and from FK to RGDP at the $1 \%$ significance level. These results tend to indicate that human and physical capitals can be employed to predict economic growth in Nigeria. Table 2 shows the ADF and PP (with intercept and a linear trend) unit root test results. 
Table 2. ADF and PP Unit Root Test Results.

\begin{tabular}{|c|c|c|c|c|c|}
\hline \multirow{2}{*}{ Variable } & \multicolumn{2}{|c|}{ ADF } & \multicolumn{2}{c|}{ PP } & \\
\hline & Level & $1^{\text {st }}$ Difference & Level & $1^{\text {st }}$ Difference & Order of integration \\
\hline RGDP & -2.048064 & $-4.316166^{* * *}$ & -2.048064 & $-4.302223^{* *}$ & I(1) \\
\hline HK & $3.531583^{* * *}$ & -0.793399 & 2.640174 & $-5.176777^{*}$ & I(0) for ADF, I $(1)$ for PP \\
\hline FK & $-5.798133^{*}$ & -3.626341 & $-5.673248^{*}$ & -3.505040 & $\mathrm{I}(0)$ \\
\hline
\end{tabular}

Note: $* * *$ and $* * *$ denote rejection of the null hypothesis at $1 \%, 5 \%$ and $10 \%$ significance level respectively. The null hypothesis is that the series contains a unit root or is non-stationary. The rejection of the null hypothesis is based on MacKinnon (1996) critical values.

Source: Author's computations.

The unit root test results suggest that the variables under investigation are integrated either in levels or at first differences. Using the ARDL procedure is therefore appropriate. Following the ARDL bounds test approach, three steps are followed to test the long run relationship among the variables. First, ordinary least square (OLS) is applied to equation 3 to test for the existence of cointegration. The optimal lag length for estimating the long term coefficients was selected using the Schwarz Information Criterion (SIC). The results of the bounds cointegration test are presented in Table 3 .

Table 3. Bounds Test for Cointegration.

\begin{tabular}{|c|c|c|}
\hline \multicolumn{3}{|c|}{ Computed F-statistic: 3.15 } \\
K=3 \\
\hline \multirow{2}{*}{ Critical value } & Lower Bound Value & Upper Bound Value \\
\hline $5 \%$ & 3.23 & 4.35 \\
\hline $10 \%$ & 2.72 & 3.77 \\
\hline
\end{tabular}

Source: Pesaran et al. (2001), Table CI (iii), Case 111: Unrestricted intercept and no trend. $\mathrm{k}$ is the number of regressors in the ARDL model.

The lower bound critical values assume that the explanatory variables are integrated of order I(0), while the upper bound critical values assume that the variables are integrated of order I(1). Consequently, if the computed F-statistic is less than the lower bound value, the null hypothesis is not rejected. On the other hand, if the computed $F$-statistic is greater than the upper bound value, the null hypothesis is rejected. However, if the computed $F$-statistic falls between the lower and upper bound values, the results are inconclusive.

Results in Table 3 suggest that the existence of a long-run relationship between economic growth, fixed capital and human capital is inconclusive. This is because the 
computed F-statistic (3.15) falls between the lower and upper bounds of the critical values at the 10 percent level. Consequently, further verification is required from the ECM results.

The next stage is to apply the ARDL model to estimate the long-run and short-run elasticities. The results are shown in Panels A and B of Table 4.

Table 4. Long-Run and Short-Run Estimates.

Panel A: Long-run estimated coefficients based on ARDL model (100)

Dependent Variable: RGDP

\begin{tabular}{|c|c|c|c|}
\hline Variable & Coefficient & t-statistics & p-values \\
\hline $\mathrm{C}$ & $1.632084^{* *}$ & 2.123933 & 0.0437 \\
\hline RGDP $(-1)$ & $0.763673^{*}$ & 6.925623 & 0.0000 \\
\hline FK & 0.026629 & 0.969360 & 0.3417 \\
\hline HK & $0.022337^{* *}$ & 2.610154 & 0.0151 \\
\hline \multicolumn{4}{|c|}{ Diagnostic statistics } \\
$\begin{array}{c}\mathrm{R}^{2}=0.84 ; \text { Adjusted } \mathrm{R}^{2}=0.83 ; \text { F-stat. }=46.91094(0.000000) ; \mathrm{LM}\left[\chi^{2}, 2\right]=3.195205 \\
(0.20240) ; \text { ARCH }\left[\chi^{2}, 1\right]=0.267364[0.6051] ; \text { ARCH }\left[\chi^{2}, 4\right]=1.327090(0.8568) ; \\
\text { RESET }=1.133206(0.2977) .\end{array}$ \\
\hline
\end{tabular}

Panel B: Error correction representation based on ARDL model (100)

Dependent Variable: $\triangle$ RGDP

\begin{tabular}{|c|c|c|c|}
\hline Variable & Coefficient & Standard Error & t-values (Prob.) \\
\hline $\mathrm{C}$ & -0.000112 & 0.012552 & $-0.008962(0.9929)$ \\
\hline$\Delta \mathrm{RGDP}(-1)$ & $0.721008^{* *}$ & 0.305771 & $2.358003(0.0273)$ \\
\hline$\Delta \mathrm{FK}$ & $0.077997^{*}$ & 0.024655 & $3.163591(0.0043)$ \\
\hline$\Delta \mathrm{HK}$ & 0.027601 & 0.023420 & $1.178483(0.2507)$ \\
\hline $\mathrm{ECM}(-1)$ & $-0.724174^{* * *}$ & 0.360965 & $-2.006219(0.0567)$ \\
\hline \multicolumn{4}{|c|}{ Diagnostic statistics } \\
\hline
\end{tabular}

$\mathrm{R}^{2}=0.43 ;$ Adjusted $\mathrm{R}^{2}=0.33 ;$ F-stat. $=4.405425$ [0.008639]; $\mathrm{LM}\left[\chi^{2}, 1\right]=0.003694$ $(0.9515) ; \operatorname{LM}\left[\chi^{2}, 2\right]=0.364275(0.8335) ; \mathrm{ARCH}\left[\chi^{2}, 1\right]=1.120444(0.2898) ; \mathrm{ARCH}$

$$
\left[\chi^{2}, 4\right]=3.028635(0.5530) \text {. }
$$

Note: $* * *$ and $* * *$ indicate significance at $1 \%, 5 \%$ and $10 \%$ level respectively. Probability values are in parenthesis in Panel B. LM denotes Breusch-Godfrey Serial Correlation test for the presence of serial correlation; $\mathrm{ARCH}$ indicates test for heteroscedasticity (No. of lags are in square brackets); RESET stands for Ramsey Regression Specification Error Test.

Panel A of Table 4 presents the estimated long run results. As expected, all the explanatory variables are correctly signed. One period lagged growth is a significant factor explaining economic growth in Nigeria. 
Consequently, 1 percent change in lagged growth is associated with an increase in economic growth of about 76 percent. The coefficient of fixed capital is not statistically significant. The result is hardly surprising, given the nature and development of physical capital in Nigeria. It is known that physical capital in the form of roads, railway, bridges and the like, all important stimulants of long-term growth are in various degrees of neglect. Human capital coefficient is statistically significant at the $5 \%$ level. Thus, if expenditure on education and health increases by $1 \%$, on the average, economic growth rises by about $3 \%$.

The diagnostic statistics are quite satisfactory. Given the adjusted $\mathrm{R}^{2}$ of 0.84 , it indicates that $84 \%$ of variation in growth is explained by its own lagged values, fixed capital stock and the stock of human capital. The F-statistic is significant, indicative of joint significance of estimated coefficients. The LM test for autocorrelation shows acceptance of the null hypothesis of no serial autocorrelation. The ARCH test results accept the null hypothesis of homoscedasticity. The Ramsey regression specification error test is satisfactory and indicates that the long-term growth function for the Nigerian economy does not suffer specification bias.

The results of the error correction representation of the selected ARDL model are presented in Panel B of Table 4. Of note is that all the explanatory variables are correctly signed and are statistically significant with the exception of the coefficient of human capital. The result of the non-statistically significant coefficient of human capital may be interpreted as indicating that in the short run, education and health expenditures are not very significant indicators of growth in Nigeria.

The effects of education are long and that it takes time for the accumulated knowledge to be felt in production and welfare. It is also known that for Nigeria, given the shoddy nature of health and education policies over the years, the result is not surprising. The Adjusted $\mathrm{R}^{2}$ value of 0.33 shows that the independent variables employed in the model jointly accounted for 33 percent of the total variation in growth.

The F-statistic indicates joint significance of estimated coefficients. In addition, there is no serial autocorrelation of the disturbance term. The results of the ARCH tests show that there is no heteroskedasticity.

The coefficient of the error correction mechanism (ECM) is negative and statistically significant at the $10 \%$ level, indicating that a deviation in growth rate from equilibrium is corrected by as much as 72 percent the following year. The statistical significance of the ECM coefficient lends support to the existence of cointegration relationship between growth, fixed capital and human capital, thereby resolving the inconclusive case of the test for cointegration earlier reported.

To determine the stability of the aggregate production function coefficients, the cumulative sum of recursive residuals (CUSUM) and cumulative sum of squares of recursive residuals (CUSUMSQ) tests were conducted and are presented in Figures 1 and 2.

In order to establish that the coefficients of the estimated model are stable, the CUSUM and CUSUMSQ are expected to stay within the $5 \%$ critical line.

The straight lines in the graph present critical bounds at $5 \%$ significance level. As shown in Figures 1 and 2, the CUSUM and CUSUMSQ plots do not cross the $5 \%$ critical lines. It is therefore concluded that the estimated coefficients are stable over the entire sample period. 


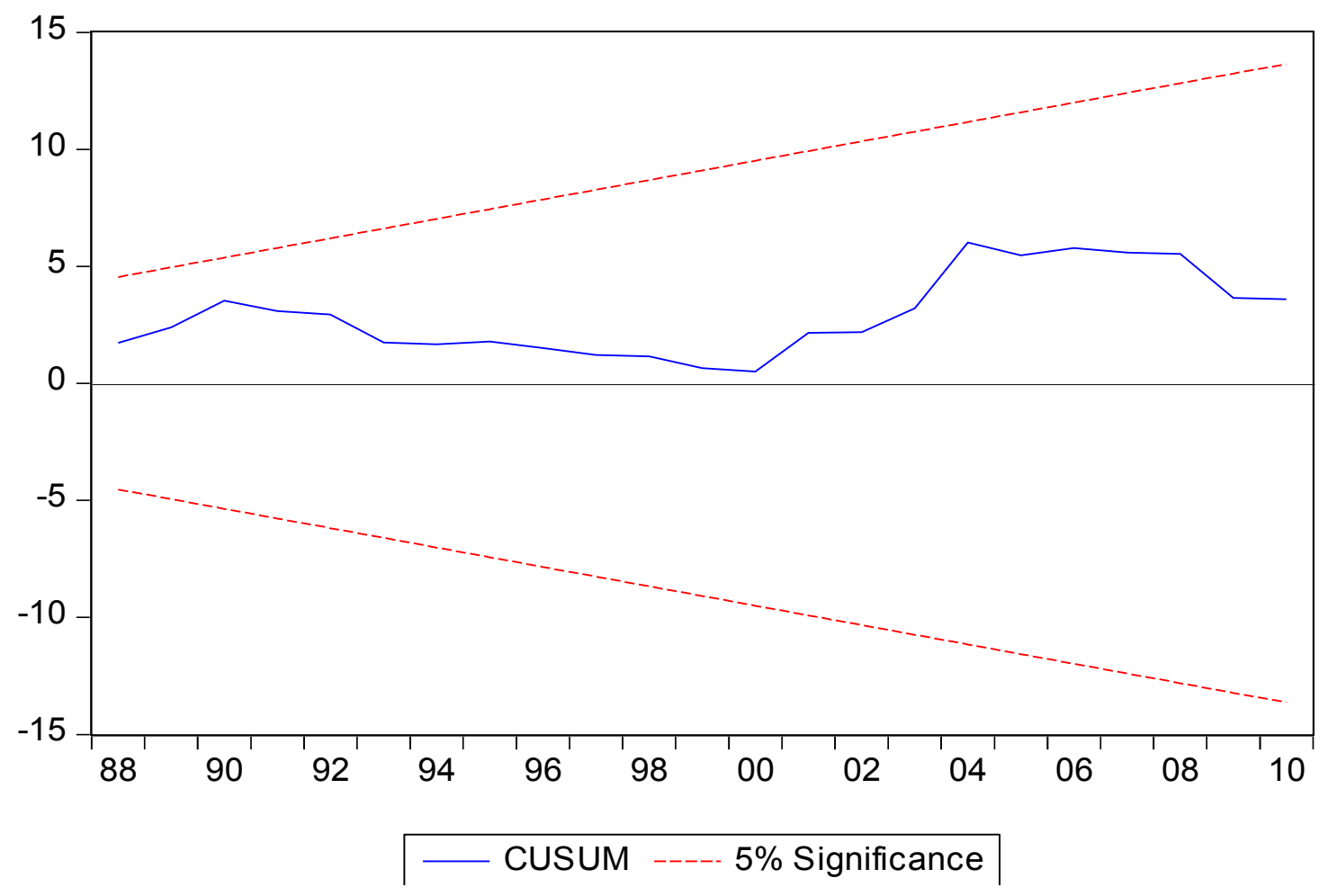

Figure 1. CUSUM Test.

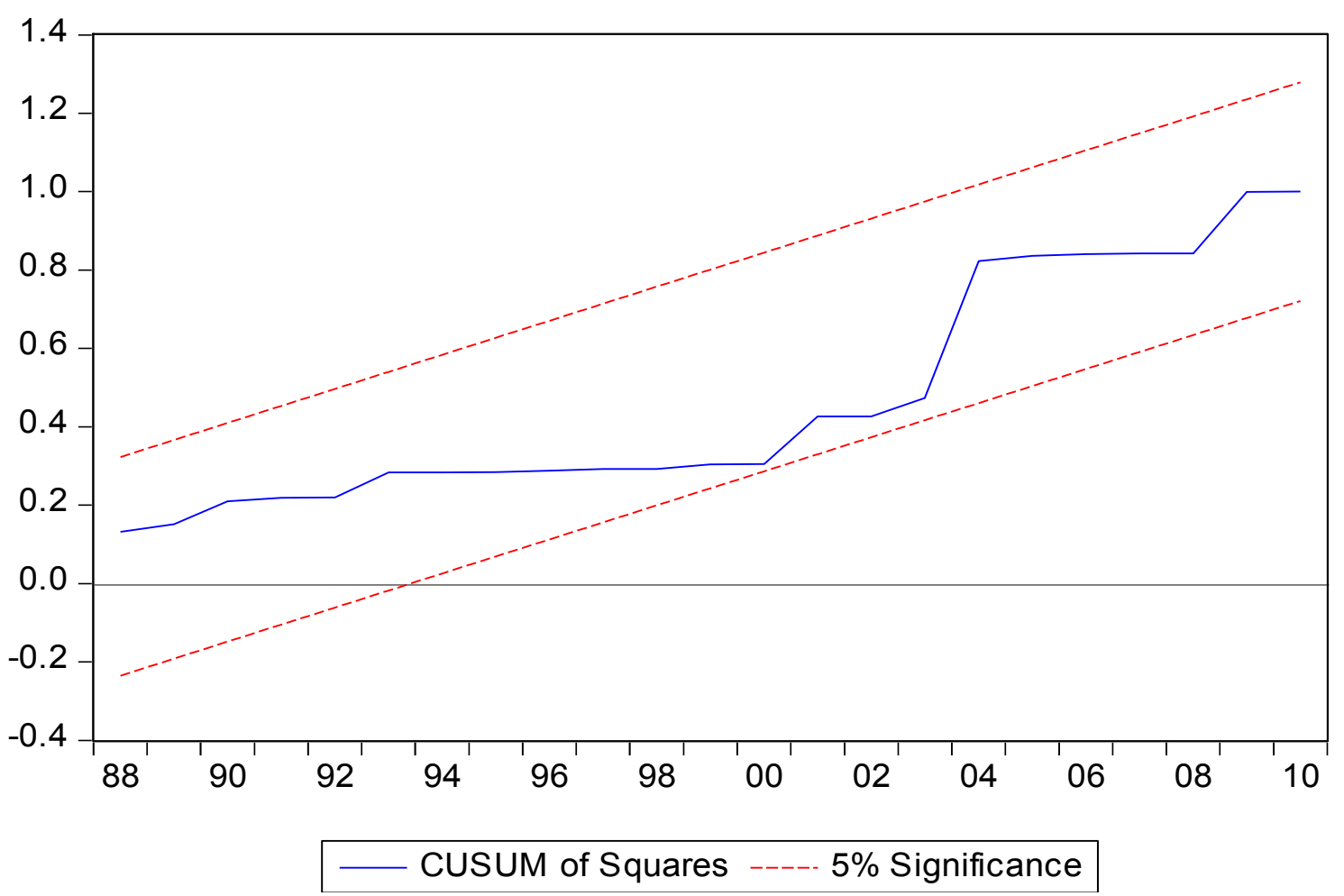

Figure 2. CUSUM Squares Test. 


\section{CONCLUSIONS}

The paper was aimed at investigating the criticality of human capital development on Nigeria's economic growth and rejuvenation within the autoregressive distributed lag framework. The study covered the period from 1981 to 2010, using data from secondary sources. There was empirical evidence of a long-run relationship between economic growth, human and fixed capital in the period under investigation.

Fixed capital and human capital were found to be positively associated with growth in both the short and long run. In the long-run, while human capital was found to be a statistically significant growth factor at the $5 \%$ level, fixed capital was not. In the short-run, economic growth was found to be significantly influenced by fixed capital, while human capital was not, a result that is not surprising, given the various bottlenecks faced by the health and education sectors in the country. From the results, causality runs from both human capital and fixed capital to growth, implying that economic growth is predictable given the changes in human and physical capital development.

The policy implication from the empirical study is that education and health, though important determinants of economic growth have not been quite exploited in Nigeria's growth experience. It is therefore in the interest of the country that policies that would deliberately promote human capital be enacted and implemented, to take advantage of the largely unexploited human capital, with a view to rejuvenating the economy which has exhibited different forms of collapse since the 1980s.

\section{References}

[1] Anyanwu, J.C., Oyefusi, A., Oakhenan, H. and Dimowo, F.A. (1997). The Structure of the Nigerian Economy, Joanee Educational Ltd, Onitsha.

[2] Azariadis, C. and Drazen, A. (1990). "Threshold Externalities in Economic Development." Quarterly Journal of Economics, 105(2), 501-526.

[3] Barro, R. (1991). "Economic Growth in a Cross Section of Countries." Quarterly Journal of Economics 106(2), 407-443.

[4] Barro, R., and Lee, J. (1994). "Sources of economic growth", Carnegie-Rochester Conference Series on Public Policy, Cambridge, MA, MIT Press.

[5] Barro, R., Sala-i-Martin, X. (1997). "Technological Diffusion, Convergence, and Growth." Journal of Economic Growth, 2(1), 1-26.

[6] Becker, G.S. (1962). "Investment in human capital: a theoretical analysis", Journal of Political Economy, 70, 9-49.

[7] Chakraborty, S., and Das, M. (2005). "Mortality, human capital and persistent inequality", Journal of Economic Growth, 10, 159-192.

[8] Central Bank of Nigeria (various issues). Statistical Bulletin. Abuja, Nigeria.

[9] Collins, S. (2007). "Economic Growth in South Asia: A Growth Accounting Perspective." In S. Ahmed and E. Ghani (eds.), South Asia: Growth and Regional Integration. World Bank, Washington, DC. 
[10] Di Matteo, L. and Di Matteo, R. (1998). "Evidence on the determinants of Canadian provincial government health expenditures: 1965-1991", Journal of Health Economics, 17, 211-228.

[11] Diejomaoh, V.P. (1978). "Nigeria's Human Resources: A Preliminary Assessment" in Damachi and Diejomaoh (eds.), Human Resources and African Development. Praeger publisher, New York.

[12] Engle, R.F. and Granger, C.W.J. (1987). "Cointegration and Error Correction Representation: Estimation and Testing.” Econometrica, 55, 251-276.

[13] Hanushek, E. and Woessmann, L. (2009). "Do Better Schools Lead to More Growth? Cognitive Skills, Economic Outcomes, and Causation”. NBER Working Paper No. 14633, National Bureau of Economic Research, Massachusetts.

[14] Harbison, F.H. (1972). Human Resources as the Wealth of Nations. New York, Oxford University Press.

[15] Johansen, S. and Juselius, K. (1990), "Maximum Likelihood Estimation and Inference on Cointegration -With Applications to the Demand for Money", Oxford Bulletin of Economics and Statistics, 52, 169-210.

[16] Kalemli-Ozcan, S., Ryder, H.E., and Weil, D.N. (2000). "Mortality decline, human capital investment and economic growth", Journal of Development Economics, 62, $1-23$.

[17] Leibenstein, H. (1957). Economic Backwardness and Economic Growth: Studies in the Theory of Economic Development, New York: Wiley and Sons.

[18] Mankiw, N.G., Romer, D. and Weil, D. (1992). "A Contribution to the Empirics of Economic Growth." The Quarterly Journal of Economics 107(2), 407-437.

[19] Mushkin, S.J., (1962). "Health as an investment”, Journal of Political Economy, 70, 125-157.

[20] Pesaran, M. H., Shin, Y. and Smith, R.J. (2001). "Bounds testing approaches to the analysis of level relationships". Journal of Applied Econometrics, 16, 289-326.

[21] Pritchett, L. (1996). "Where Has All the Education Gone?” World Bank Policy Research Working Paper 1581, Washington, DC.

[22] Sachs, J. and Warner, A. (1997). "Sources of slow growth in African economies", Journal of African Economies, 6, 335-337.

[23] Son, H.H. (2008). "Explaining Growth and Inequality in Factor Income: The Philippines Case". ADB Economics Working Paper Series No. 120, Economics and Research Department, Asian Development Bank.

[24] Strauss, J. and Thomas, D. (1998). "Health, nutrition and economic development", Journal of Economic Literature, 36, 766-817. 
[25] Thornton, J. (2002). "Estimating a health production function for the US: some new evidence", Applied Economics, 34, 59-62.

[26] Trostel, P., Walker, L. and Woolley, P. (2002). "Estimates of the Economic Return to Schooling for 28 Countries." Labour Economics, 9, 1-16.

[27] UNESCO (2002). EFA Global Monitoring Report, Education for All: Is the World on Track? Paris. 